\title{
FUNGAL DISEASES OF ALFALFA IN ISMAILIA GOVERNORATE
}

\author{
EL-GARHY, A.M. and D.A. EL-WAKIL \\ Plant Pathology Research Institute, ARC, Giza, Egypt. \\ (Manuscript received 15 June 2014)
}

\begin{abstract}
A survey of fungal diseases on alfalfa (cv. Sewa) in Ismailia governorate was carried out during 2011 and 2012. Percentages of infection were determined in five districs. Ismailia district, however, showed the highest percentage of infection by root rot / wilt disease and foliage diseases (0.0-60.0\%). Data indicated that the major fungal diseases affecting alfalfa in Ismailia governorate are damping-off and root-rot caused by Rhizoctonia solani and vascular wilt caused by Fusarium oxysporum and Vertcillium albo-atrum. The most important fungal foliar diseases were black stem (Phoma medicaginis) anthracnose (Colletotrichum trifolii), leaf spot (Stemphylium botryosum and Alternaria sp.), Downy mildew (Peronospora sp.) and rust (Uromyces trifolii). On the other hand, $R$. solani gave the highest percentage in isolation trials from alfalfa seeds followed by F. oxysporum, while Macrophominia phsolina was the least isolated. Also, $R$. solani was the most pathogenic fungus to alfalfa seeds in laboratory, followed by $S$. sclerotiorum, while $M$. phaseolina was the least.
\end{abstract}

\section{INTRODUCTION}

Alfalfa (Medicago sativa L.) or Lucerne, the oldest and the most important forage crop in the world, is currently cultivated as a nitrogen source and soilconserving perennial crop in low-imput agricultural systems (Stuteville and Erwin, 1990). In Egypt, it is one of the most promising forage crops in the new reclaimed areas (Mohamed et al., 1992). There is a gab between the demand and the consumption of green forages, especially in the summer season where the available forages are limited. Several soil borne fungi are reported as the causal fungal organisms of root-rot, wilt and crown rot diseases, i.e. Rhizoctonia solani , Fusarium solani, Macrophomina phaseolina, Selerotium rolfsii, Sclerotinia sp., Fusarium oxysporum and Vertcillium sp. (El-Barougy, 1997and Couture et al., 2002). Also, several airborne fungi were recorded as the causal pathogens of leaf spot, downy mildew, rust, black stem and anthracnose diseases, i.e. Alternaria sp., Stemphylium botryosum, Peronospora trifrumolio, Uromyces striatus, Phoma medicaginis and Colletotrichum sp. (Billar 1989, El-Barougy, 1997, Naseri \& Marefat, 2008 and AbdelMonaim et al., 2012). Phoma medicaginis var. medicaginis, Pseudopeziza medicaginis, Peronospora trifoliorum, Stemphylium botryosum, Colletotrichum trifolii and Rhizoctonia solani were the important diseases occurring in Ankara (Mishrace, 2006). 
However, these various diseases usually cause economic losses in plants stand and yield.

In Egypt, mild to acute fluctuation in temperature and humidity started to occur during the last decade, therefore, prevalence, time and duration of the disease symptoms appearance began to change. The present work aimed to study the fungal diseases attacking roots and foliage of alfalfa in Ismailia governorate and their relative importance as will as pathogenic potential with special reference to the associated seed -borne fungi.

\section{MATERIALS AND METHODS}

\section{Field survey:}

A field survey was carried out in five locations: namely Ismailia, Fayed, El-Tal El-Kabeer, El-Quntra Gharb and El-Quntra Sharq, which represent the most producing areas of the crop. The survey was carried out during 2010/2011and 2011/2012 seasons. The percentages of roots and foliage fungal diseases were determined in twenty five random diseased plants picked diagonally from each field for laboratory isolation.

\section{Isolation and identification of the associated fungi:}

Roots, stems and leaves of the diseased plants showing typical symptoms of root rot, wilt, crown rot, black stem and leaf spot were washed several times with running tap water. Infected tissues of each sample were cut into small pieces and separately surface-sterilized in $2 \%$ sodium hypochlorite for $3 \mathrm{~min}$. then washed twice in sterilized distilled water. The sterilized plant pieces were dried and directly plated on PDA medium, (5 pieces / Petri-dish), then incubated at $25 \mathrm{C}^{\circ}$ for 7 days. Emerging fungi were purified and identified microscopically according to their morphological characters according to Barnett and Hunter (1998). Also, the identification was confirmed by the staff of Mycology Research \& Disease Survey Department, Plant Path. Res. Inst., Agric. Res. Center, Giza, Egypt. Stock cultures were maintained on PDA slant and kept in a refrigerator at $5 \mathrm{C}^{\circ}$ for further studies.

\section{Pathogenicity test:}

The pathogenic potential of each of the most important fungi of rot and wilt diseases, i.e. R. solani, F. solani, F. oxysporum, V. albo-atrum, M. phaseolina, S. sclerotiorum and Sclerotium rolfsii, was determined. The fungal inocula were prepared by growing each fungus on autoclaved sorghum medium in $500 \mathrm{ml}$ glass bottles at $25 \mathrm{C}^{\circ}$ for two weeks. Formalin- disinfested pots ( $25-\mathrm{cm}$-diam.) containing formalindisinfested sandy soil ( $4 \mathrm{~kg} /$ pot ) were infested separately with each fungal growth at the rate of $2 \%(\mathrm{w} / \mathrm{w})$. Four pots were used for each treatment. Apparently healthy twenty seeds ( $\mathrm{cv}$. Sewa) were sown in each pot 7days after soil infestation. Disease severity index(DSI) of root rot was recorded using scale proposed by Hankock (1985). 
The inocula of the most important foliar fungi, i.e. Cereospora sp., Phoma medicaginis, Colletotrichum trifolli, Stemphylium botryosum and Alternaria sp. were prepared from 14- days- old growth grown on PDA medium as spore suspensions ( $10^{5}$ spores / $\mathrm{ml}$ ). The inocula were sprayed on 45 days old plants. Inoculated plants were kept under high humidity for 3 days. Diseases Severity index (D.S.I) of crown necrosis, leaf spot and black stem were recorded using scales proposed by Turner and Van Alfan (1983) and Boland and Brochu (1989), respectively.

\section{Isolation of alfalfa seeds associated fungi :}

\section{- Source of seed samples:}

Twenty seed samples of Alfalfa (cv. Sewa) were collected from five districts during summer season 2012, i.e. Fayed, El-Tal El-Kabeer, El-Quantara Sharq, ElQuantara Gharb and Ismailia. Twenty five seeds were plated in a $12-\mathrm{cm}$ diameter Petri dish (8 dishes) containing PDA medium and incubated at $20 \pm 2 \mathrm{C}^{\circ}$ for 4 days under cool white fluorescent light with alternating cycles of 12-h light and 12-h darkness (Uzma and Nusrat, 2011). Seeds were examined under a stereoscopic microscope to determine the percentage of infected seeds. The occurrence of different fungal species was recorded according to the recommended methods of Mathur and Knogsdal (2003).

\section{Identification of the isolated fungi:}

The isolated fungi were identified based on their habit characters under stereomicroscope and light microscope according to Barnett and Hunter (1998).

\section{Determination of aggressiveness for the seed fungal isolates:}

The aggressiveness of five fungi namely: R. solani, F. solani, F. oxysporum, M. phaseolina and $S$. sclerotirum was tested after they were grown on water agar medium at $24 \pm 2 \mathrm{C}^{\circ}$. Seeds (cv. Sewa) were surface sterilized with $2 \%$ sodium hypochlorite solution for $3 \mathrm{~min}$, washed several times with sterilized water and 10 seeds per plate were placed onto the prepared fungal cultures. Seeds also were placed on water agar plates as uninoculated control. The plates were incubated at $24 \pm 2 \mathrm{C}^{\circ}$ for one week before the disease ratings were determined. Each fungal isolate was considered as a treatment and four replicates (4 plates) for each were used. The rating scale for aggressiveness on all seeds was measured as proposed by Zhang and Yang, (2000) as follow:

$0=$ seed germinated without visible infection, $1=$ germinated with light discoloration on roots, 2 = germinated with short severely discolored roots, 3 = died after germination, 4 = died before germination. Measurement of aggressiveness of all isolates was calculated as a disease index from the following equation:

DI $=\underline{\text { Sum of (Disease score } x \text { no. seeds with that score) }}$

No. of seeds in sample $x$ highest rating category 


\section{Statistical analysis of the data:}

The data on disease severity was subjected to single factor analysis of variance (CRD).

\section{RESULTS AND DISCUSSION}

\section{1- Diseases survey:}

Data presented in Table (1) indicate that plants with symptoms of root-rot / wilt, leaf spot and rust were found in all inspected fields, but the average percentage of infection varied from one district to another. In general, average percentages of infection were highest in Ismailia district followed by El Quantara Sharq. While, ElQuantra Gharb district showed the lowest of infection percentages. Rust infection reached $60 \%$ in Ismailia district and 47.5, 42.5 and $40.0 \%$ at El-Tal El-Kabeer, Fayed and El-Quantara Sharq, respectively. On the other hand, infection by black stem, anthracnose and downy mildew at El-Quantara Gharb was absent $(0.0 \%)$ and anthracnose was not noted in Fayed district. The present results are somewhat similar to those obtained by Billar (1989), Naseri and Marefat ( 2008) with respect to the multiplicity of diseases of alfalfa which varied in kind and frequency from one location to another.

Table 1. Average percentages of infection by fungal diseases on Alfalfa plants at five districts of Ismailia governorate.

\begin{tabular}{|c|c|c|c|c|c|c|c|}
\hline \multirow{2}{*}{ District } & \multirow{2}{*}{ NSF* } & \multicolumn{6}{|c|}{ Average percentage of infection } \\
\hline & & Root-rot & $\begin{array}{l}\text { Black } \\
\text { stem }\end{array}$ & Anthracnose & $\begin{array}{l}\text { Leaf } \\
\text { snot }\end{array}$ & $\begin{array}{l}\text { Downy } \\
\text { mildew }\end{array}$ & Rust \\
\hline Ismailia & 9 & 8.7 & 37.6 & 18.2 & 41.2 & 15.4 & 60.0 \\
\hline Fayed & 6 & 5.4 & 12.4 & 0.00 & 18.8 & 5.6 & 42.5 \\
\hline El-Tal El-Kabeer & 7 & 6.3 & 12.5 & 9.3 & 23.7 & 8.1 & 47.5 \\
\hline El-Quantara Sharq & 5 & 2.1 & 0.00 & 0.00 & 9.3 & 0.00 & 26.5 \\
\hline El-Quantara Gharb Gharb & 6 & 8.3 & 12.5 & 13.0 & 21.0 & 8.9 & 40.0 \\
\hline Mean & & 6.2 & 15.0 & 8.1 & 22.8 & 7.6 & 43.3 \\
\hline
\end{tabular}

NSF $*=$ number of surveyed fields.

\section{2-Isolation and identification of the causal organisms:}

\section{A- Plant roots:}

Isolation from rotted roots yielded 8 fungi namely: $R$. solani, $F$. solani, $F$. oxysporum (Fig.1), Fusarium sp., V. albo-atrum, M. phaseolina, S. rolfsii, and $S$. 
sclerotiorum ( Table, 2, Fig.2). All fungi, were isolated from samples of Ismailia and Fayed, whereas M. phaseolina was not isolated from samples of El- Tal El-Kabeer and El-Quantara Sharq, Gharb ) Also, S. rolfsii was not isolated from samples of El Tal ElKabeer and El Quantra Gharb. Other fungi were found at all locations at different frequencies. The variation in the kind and frequency of different fungi isolated from plants growing at different locations could be attributed to the variation in environmental conditions and / or the cropping systems. F. oxysporum followed by $R$. solani and Fusarium sp. recorded the highest means (29.00, 19.70 and $19.00 \%)$ of frequencies in isolation from all the locations tested, while S. rolfsii ( $2.6 \%$ ) and $M$. phaseolina $(2.7 \%)$ recorded the least percentages. These results are in agreement with those of Salas and Stack (1987) who found that F. oxysporum was the most common fungus isolated from alfalfa infected roots. In this respect, Uddin et al. (1991) mentioned the fusaria isolated from crown rot of alfalfa in north Nevada survey were F. solani $(43.0 \%)$, F. acuminatum $(36.0 \%), \quad$ F. oxysporum $(17.0 \%), F$. sambucinum (3.0\%) and F. avenaceum (1.0\%). Also, Several fungi including $R$. solani, F. oxysporum, V. albo-atrum and C. trifolli were isolated from diseased plants as reported locally by El-Barougy ( 1997).

Table 2. Frequency of root infecting fungi isolated from diseased alfalfa plants.

\begin{tabular}{|l|c|c|c|c|c|c|c|c|c|}
\hline \multirow{2}{*}{ District } & \multirow{2}{*}{ NSF* } & \multicolumn{7}{|c|}{ Frequency \% } \\
\cline { 3 - 10 } & & $\mathrm{A}$ & $\mathrm{B}$ & $\mathrm{C}$ & $\mathrm{D}$ & $\mathrm{E}$ & $\mathrm{F}$ & $\mathrm{G}$ & $\mathrm{H}$ \\
\hline Ismailia & 8 & 28.3 & 6.3 & 21.9 & 15.6 & 9.3 & 9.3 & 3.1 & 6.2 \\
\hline Fayed & 5 & 12.5 & 4.2 & 41.6 & 16.7 & 8.3 & 4.2 & 4.2 & 8.3 \\
\hline El-Tal El-Kabeer & 5 & 16.7 & 8.3 & 16.7 & 33.3 & 16.7 & 0.00 & 0.00 & 8.3 \\
\hline El-Quantara Sharq & 10 & 17.6 & 5.9 & 29.4 & 11.8 & 17.6 & 0.00 & 5.9 & 11.8 \\
\hline El-Quantara Gharb & 5 & 23.5 & 5.9 & 35.4 & 17.6 & 11.7 & 0.00 & 0.00 & 5.9 \\
\hline Frequency( Total) & & 98.6 & 30.6 & 145 & 95 & 63.6 & 13.5 & 13.2 & 40.5 \\
\hline Mean & & 19.7 & 6.1 & 29.0 & 19.0 & 12.7 & 2.7 & 2.6 & 8.1 \\
\hline
\end{tabular}

NSF $*$ number of surveyed fields.
$\mathrm{A}=$ R. solani
$\mathrm{B}=$ F. solani
$\mathrm{E}=V$. albo-atrum
$\mathrm{F}=$ M. phaseolina
$\mathrm{C}=\mathrm{F}$. oxysporum
$\mathrm{D}=$ Fusarium $\mathrm{sp}$.
$\mathrm{G}=S$. rolfsii
$\mathrm{H}=$ S. sclerotiorum 


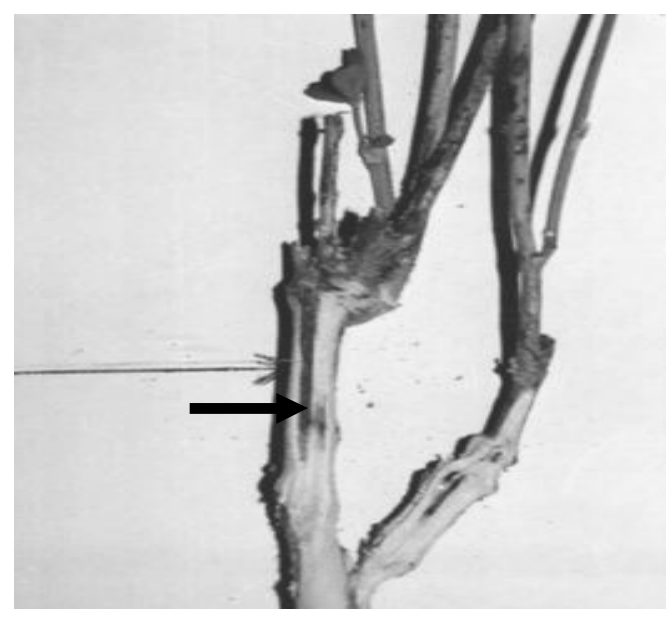

Fig. 1. Symptoms of stem infection by ( F. oxysporum ).

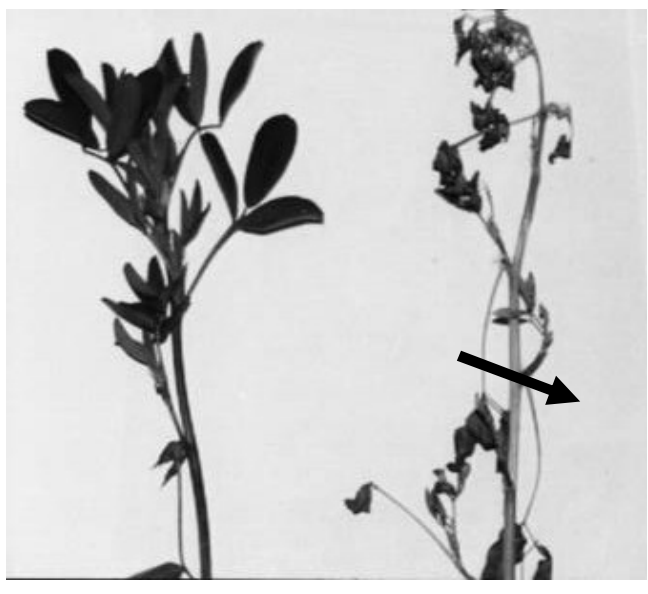

Fig. 2. Symptoms of foliage wilt caused by $S$. sclerotiorum infection.

\section{B- Foliage diseases :}

The fungi isolated from the infected foliage were: Phoma medicaginis (Fig.3), Colletotrichum trifolli (Fig.4), Colletotrichum sp., Cercospora sp., Stemphylium botryosum, Alternaria sp., Helminthosporium sp., and Pseudopeziza sp. (Table 3). Stemphylium botryosum (24.4\%), Alternaria sp.(21.7\%), Colletotrichum sp. (16.6\%) and Phoma medicaginis (13.3\%) however, recorded the highest means of frequencies in isolation trials., while, Pseudopeziza sp. and Cercospora sp. recorded $0.9 \%$ and 3.87 respectively. On the other hand, $P$. medicaginis, Colletotrichum sp., $S$. botryosum and Alternaria sp. were present in samples of all districts. In this respect, Billar (1989) mentioned the presence of summer and spring black stem and leaf spot ( $P$. medicaginis) Stemphylium leaf spot (Stemphylium sp.) and anthracnose (Colletotrichum sp.) among the fungal diseases affecting alfalfa plants. 


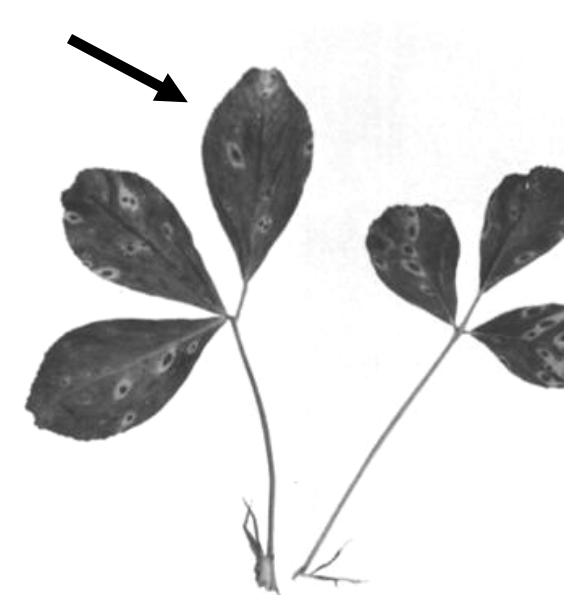

Fig. 3. Symptoms of leaf spot caused by Phoma medicaginis.

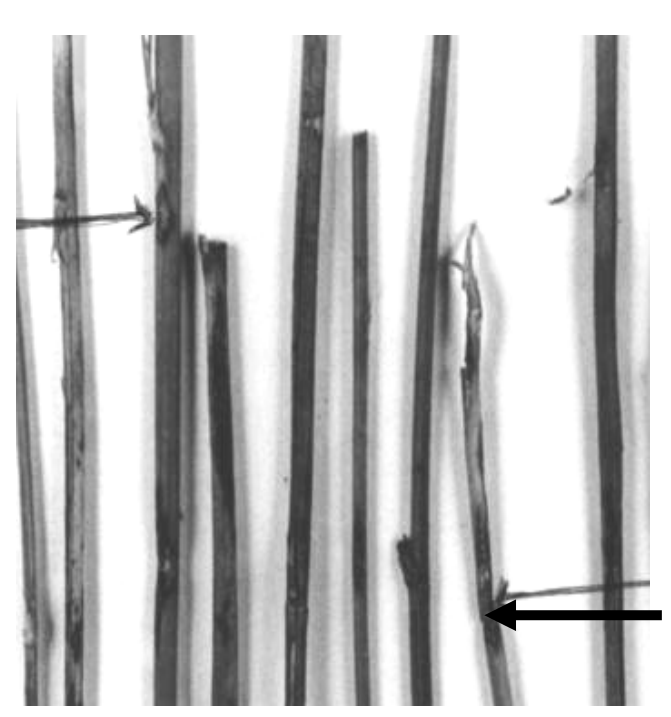

Fig. 4. Symptoms of stem rot caused by Colletotrichum trifolii

Table 3. Frequency of fungi isolated from diseased A foliage of alfalfa.

\begin{tabular}{|l|c|c|c|c|c|c|c|c|c|}
\hline \multirow{2}{*}{ Frequency } & \multirow{7}{*}{ N Frequency of fungi isolated from foliar diseased of alfalfa } \\
& NSF & \multicolumn{7}{|c|}{ plants. } \\
\cline { 3 - 13 } & & A & B & C & D & E & F & G & H \\
\hline \multirow{2}{*}{ Ismailia } & 9 & 7.4 & 14.8 & 14.8 & 10.4 & 22.2 & 18.5 & 7.4 & 4.5 \\
\hline Fayed & 6 & 12.5 & 0.00 & 25.0 & 0.00 & 25.0 & 37.5 & 0.00 & 0.00 \\
\hline El-Tal El-Kabeer & 7 & 9.1 & 18.2 & 9.1 & 0.00 & 36.4 & 18.2 & 9.1 & 0.00 \\
\hline El-Quantara Sarq & 5 & 33.3 & 0.00 & 16.7 & 0.00 & 16.7 & 16.7 & 16.7 & 0.00 \\
\hline El-Quantara Gharb & 6 & 4.3 & 13.0 & 17.4 & 8.7 & 21.7 & 17.4 & 17.4 & 0.00 \\
\hline Frequency ( Total) & & 66.6 & 46.0 & 83.0 & 19.1 & 122 & 108.3 & 50.6 & 4.5 \\
\hline Mean & & 13.3 & 9.2 & 16.6 & 3.8 & 24.4 & 21.7 & 10.1 & 0.9 \\
\hline
\end{tabular}

NSF $*$ number of surveyed fields.
$\mathrm{A}=$ Phoma medicaginis,
$\mathrm{B}=$ Colletotrichum trifolli,
$\mathrm{C}=$ Colletotrichum $\mathrm{sp}$.
$\mathrm{D}=$ Cercospora sp.,
$\mathrm{E}=$ Stemphylium botryosum.,
$\mathrm{F}=$ Alternaria sp.,
$\mathrm{G}=$ Helmenthosporium sp. \&
$\mathrm{H}=$ Pseudopeziza sp.,

\section{2- Pathogenicity tests:}

\section{A- Root- infecting fungi :}

All fungi isolated from infected roots of alfalfa plants were found to be pathogenic, causing different degrees of pre- and post-emergence damping-off. The highest percentage of pre-emergence damping-off was caused by $R$. solani $(70.0 \%)$, followed by $S$. rolfsii (31.25\%) and F. solani (28.75\%), while the lowest percentages 
was caused by M. phaseolina (17.5 \%) and F. oxysporum (16.25\%). The lowest percentage of survival was recorded with $R$. solani $(17.5 \%)$, while the highest was with M. phaseolina (77.5\%). Zwatz ( 1991)found that $R$. solani and F. solani as the most destructive pathogens attacking alfalfa roots, while $V$. albo-atrum caused the highest degree of wilt. Beshir et al. (1997) mentioned that $R$. solani was the most destructive causing the highest percentage of pre-emergence damping-off, followed by F. solani and P. debaryanum.

Table 4. Effect of soil infestation with fungi on damping-off disease incidence 15 and 45 days, respectively.

\begin{tabular}{|c|c|c|c|c|}
\hline \multirow[b]{2}{*}{ Tested fungi $\mathrm{c}$} & \multicolumn{2}{|c|}{ Damping-off } & \multirow[b]{2}{*}{$\begin{array}{c}\text { Survivals } \\
\text { (\%) }\end{array}$} & \multirow[b]{2}{*}{ DSI* } \\
\hline & $\begin{array}{c}\text { Pre- } \\
\text { emergence } \\
\% \\
\end{array}$ & $\begin{array}{c}\text { Post- } \\
\text { emergence } \\
\% \\
\end{array}$ & & \\
\hline Rhizoctonia solani & 70.0 & 12.50 & 17.5 & 3.92 \\
\hline Fusarium solani & 28.75 & 22.50 & 48.75 & 1.92 \\
\hline Fusarium oxysporum & 16.25 & 46.25 & 37.50 & 3.17 \\
\hline Verticillium albo-atrum & 21.25 & 37.50 & 41.25 & 2.25 \\
\hline Macrophomina phaseolina & 17.5 & 5.00 & 77.5 & 1.25 \\
\hline Scelrotium rolfsii & 31.25 & 15.00 & 53.75 & 1.84 \\
\hline Sclerotinia sclerotiorum & 23.75 & 13.75 & 62.50 & 1.42 \\
\hline Control ( Without fungus) & 2.5 & 0.00 & 97.5 & Healthy \\
\hline L.S.D. at $5 \%$ & 8.36 & 4.64 & 9.31 & \\
\hline
\end{tabular}

* DSI :Disease severity index.

\section{B- Foliage - infecting fungi :}

Data in Table (5) indicated that all the tested fungi were pathogenic. $P$. medicaginis was the most aggressive fungus with leaf spot severity of, $7.4 \%$ followed by $S$. botryosum (5.8\%) and Alternaria sp. (4.7\%) with limited numbers of small brown necrosis mainly on the leaves and stems. Colletotrichum trifolii was the only fungus causing typical anthracnose symptoms on stem, crown and leaf with disease severity of $1.5,12.3$ and $6.5 \%$, respectively. These results are in agreement with Basu (1983), who reported that high incidences of $P$. medicaginis, followed by $C$. trifolii and P. megasperma were recorded on alfalfa plants. Lenssen et al. (1991) stated that $C$. trifolii was the fungus responsible for causing alfalfa anthracnose type symptoms, whereas, Boland and Brochu (1989) reported C. desructivum as the main causal of anthracnose in Canada. 
Table 5. Pathogenicity of foliage infecting fungi on Alfalfa and the characteristics of the appeared symptoms.

\begin{tabular}{|l|c|c|c|l|}
\hline \multirow{2}{*}{ Tested fungi } & \multicolumn{3}{|c|}{$\begin{array}{c}\text { Disease severity of } \\
\text { infection on : }\end{array}$} & \multirow{2}{*}{ Symptoms on alfalfa plants } \\
\cline { 2 - 5 } & Leaf & Stem & Crown & \\
\hline Phoma medicaginis & 7.4 & 3.2 & 0.0 & Spring black stem and leaf spot \\
\hline Colletotrichum trifolii & 1.5 & 12.3 & 6.5 & Anthracnose and crown rot or spot. \\
\hline Stemphylium botryosum & 5.8 & 2.6 & 0.0 & Leaf spot \\
\hline Alternaria sp. & 4.7 & 1.8 & 0.0 & Leaf spot \\
\hline Cercospora sp. & 2.1 & 0.0 & 0.0 & Summer black, stem and leaf spot \\
\hline \multicolumn{1}{|c|}{ Control } & 0.0 & 0.0 & 0.0 & \\
\hline L.S.D. at $5 \%$ & 0.21 & 0.15 & 0.04
\end{tabular}

\section{3 - Fungi associated with alfalfa seeds :}

Fungi were usually isolated from seeds (Table 6) where Rhizoctonia solani gave the highest frequency (27.02\%), followed by Fusarium oxysporum (24.32\%). Fusarium solani recorded moderate frequency (13.51 \%) and Macrophomina phaseolina was the least (5.4\%). Data also showed that Ismailia district was higher in frequency of fungi $(29.73 \%)$ followed by El- Tal El-Kabeer $(24.32 \%)$, while ElQuantra Sharq was the least $(8.10 \%)$. Several fungi were isolated from ten varieties of legume seeds Quantara Sharq where $R$. solani, Pythium aphanidermatum and $S$. sclerotiorum recorded the highest frequency (Abdullah, 2010). Twenty four genera and thirty five species of fungi were isolated from alfalfa seeds (Al-Askar et al., 2013). Alternaria alternata, Cladosporium sp., Aspergillus sp., Stemphylium sp., and Penicillium sp., were the genera most commonly found as saprophytic fungi, while Stemphylium botryosum and Fusarium incarnatum were common pathogenic fungi. Also, $C$. trifolii and $R$. solani gave the highest percentages of rotted alfalfa seeds (31.6 and $26.45 \%$, respectively) followed by $F$. equiseti $(17.45 \%$ ) and $F$. ncornatum (15.7\%).

Table 6. Occurrence of fungi on alfalfa seeds, collected from five districts in Ismailia governorate, during (2012) season.

\begin{tabular}{|c|c|c|c|c|c|c|c|c|}
\hline \multirow{2}{*}{ District } & \multicolumn{8}{|c|}{ Disease index on seeds of Petri dishes } \\
\hline & $A$ & B & C & D & $E$ & $\mathrm{~F}$ & Total & Frequency \\
\hline Ismailia & 3 & 2 & 3 & 1 & 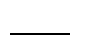 & 2 & 11 & 29.73 \\
\hline Fayed & 2 & 1 & 2 & 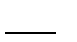 & 1 & 2 & 8 & 21.62 \\
\hline El-Tal El-Kabeer & 3 & 1 & 2 & - & 2 & 1 & 9 & 24.32 \\
\hline El-Quantara Sharq & 1 & 1 & 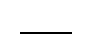 & 1 & 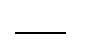 & $\underline{-}$ & 3 & 8.10 \\
\hline El-Quantara Gharb & 1 & 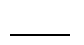 & 2 & 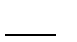 & 1 & 2 & 6 & 16.21 \\
\hline Total & 10 & 5 & 9 & 2 & 4 & 7 & 37 & 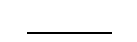 \\
\hline Frequency & 27.02 & 13.51 & 24.30 & 5.40 & 10.81 & 18.91 & . & _ \\
\hline
\end{tabular}




\section{Pathogenicity of the associated fungi to seeds:}

Data in Table (7) expressed in terms of disease index showed that $R$. solani was more aggressive(0.95) than the other fungi, followed by $S$. sclerotiorum (0.91), $F$. oxysporum was moderate $(0.85)$ and $M$. phaseolina was the least pathogenic $(0.52)$. Some fungi can infect seeds before harvest but many of these fungi were not favored by storage conditions. Similar results were obtained by Pand et al.(2005). Pathogenic fungi viz. Fusarium moniliforme, Fusarium oxysporum, Macophomina phaseolina and Rhizoctonia solani were isolated from chickpea seeds. Several legume crops were tested under laboratory conditions for susceptibility to the pathogen isolated from seeds showed that $S$. sclerotiorum was more aggressive followed by $R$. solani ( Abdullah, 2010).

Table 7. Aggressiveness of seed isolates using Petri dish technique:

\begin{tabular}{|l|c|c|c|c|c|}
\hline \multirow{2}{*}{ Fungus } & \multicolumn{4}{|c|}{ Disease index on seeds } & \multirow{2}{*}{ Mean } \\
\cline { 2 - 5 } & 1 & 2 & 3 & 4 & \\
\hline Rhizoctonia solani & 0.98 & 0.95 & 0.95 & 0.93 & 0.95 \\
\hline Fusarium solani & 0.53 & 0.63 & 0.55 & 0.58 & 0.57 \\
\hline Fusarium oxysporum & 0.75 & 0.88 & 0.93 & 0.83 & 0.85 \\
\hline Macrophomina phasolina & 0.53 & 0.55 & 0.50 & 0.48 & 0.52 \\
\hline Sclerotinia sclertiorum & 0.85 & 0.90 & 0.92 & 0.98 & 0.91 \\
\hline Control & 0.0 & 0.0 & 0.0 & 0.0 & 0.0 \\
\hline
\end{tabular}

L.S.D at $5 \%=0.11$

Based on the obtained results, it is recommended that seed health testings should be done for the different seed lots and appropriate treatments be made before being planted. Also, disease surveys are recommended for different production areas to avoid those with high frequencies of destructive diseases.

\section{REFERENCES}

1. Abdullah, Amira H.A. 2010. Pathogenicity of fungi associated with leguminous seeds in the Eastern Kingdom of Saudi Arabia. African J. Agri. Res. 5(10): 1117-1126.

2. Abdel-Monaim, M.F., K.M. Morsy, E.A.D. Sarhan and N.M. Hamed. 2012. Influence of certain resistance inducing chemicals on alfalfa rust disease and its effect on growth parameters and yield components. Aust. J. Basic \& Appl., Sci., 6(3): 506-514. 
3. Al- Askar, A.A., K.M. Ghoneem and Y.M. Rashad. 2013. Seed borne mycoflora of alfalfa (Medicago sativa L.) in the Riyadh Region of Saudi Arabia. Annals of Microbiology, 62 (1): 273-281.

4. Barnett, H.I. and B.B. Hunter. 1998. Illustrated Genera of Imperfect Fungi. APS Press, MN, USA.

5. Basu, P.K. 1983. Survey of eastern Ontario alfalfa field to determine common fungal diseases and predominant soilborne species of Pythium and Fusarium. Can. Plant Dis. Sur., 63: $51-54$.

6. Beshir, M.B., H.R. Abdel-All, R.M. Yosef and M.K. Agha. 1997. Effect of soil types on the diseases incidence of alfalfa root-rot and wilt with special reference to its varietals reaction. Proc. $8^{\text {th }}$ Cong. Egypt. Phytopathol. Sco., Cairo. 377-390.

7. Billar, M. 1989. Survey of alfalfa diseases in Ghoute of Damascus, Syria. Arab J. Plant Prot., $7: 13$.

8. Boland, G.J. and L.D. Brochu. 1989. Colletotrichum desructivum on alfalfa in Ontario and cultivar response to antharacnose. Can. J. Plant Pathol., 11 (3): 303- 307.

9. Couture, L.C., C. Dhont, F.P. Chalifour, R. Drapeau, G. Tremblay, Y. Castonguay, G. Belanger and P. Nadeau. 2002. Fusarium root and crown rot in alfalfa subjected to autumn harvests. Can. j. Plant Sci., 82: 621-624.

10. El-Barougy, Ebtehag S.H. 1997. Studies on root-rot and wilt diseases of alfalfa. Ph.D. Thesis., Fac. Agric., Suez Canal Univ., Ismailia,145pp.

11. Hankock, J.G. 1985. Fungal infection of feeder rootlets of alfalfa. Phytopathology, $75: 1112-1120$.

12. Mathur, S.B. and O. Knogsdal. 2003. Common Laboratory Seed Health Testing Methods for Detecting Fungi.1 ${ }^{\text {st }}$ ed. International Seed Testing Association, Bassersdorf, Switerland, 425pp.

13. Mishrace, C.O. 2006. Determination of the important alfalfa diseases occurring in the alfalfa growing in farms of the Faculty of Agric. of Ankara Univ. Tarim bilimleri dergisi, 12(2): 162-165.

14. Mohamed, N.A. and M.E. Mousa. 1992. Effect on indole acetic acid on the morphology and chemical composition of alfalfa. Egypt. Agric. Res. 70(4): 11511157.

15. Naseri, B. and A.R. Marefat. 2008. Seasonal dynamics and prevalence of alfalfa fungal pathogens in Zanjan Province, Iran. Int. J. of Plant Prod., 2(4),1735-6814 (Print), 1735-8043( Online).

16. Pand, S., K.H.M. Siddique, G.K. Kishore, B. Bayaa, P.M. Guar, C.L.L. Gowda, T.W. Bretage and J.H. Crouch. 2005. Ascochyta blight of chickpea (Cicer arietinum L.) : 
a review of biology, pathogenicity, and disease management. Assuit J. Agric. Res., 65: 317-332.

17. Salas, B. and R.W. Stack. 1987. Incidence of fungi associated with roots and crown of decling alfalfa in North Dakota (Abstr.). Phytopathology, 77: 1759.

18. Seif El-Nasar, H.I. and K.T. Leath. 1983. Crown and root fungal diseases of alfalfa in Egypt. Plant Dis., 65 : 509 - 511 .

19. Stuteville, L.D. and D.C. Erwin. 1990. Compendium of alfalfa diseases. APS Press, St Paul, MN, USA.

20. Turner, V. and N.K. Van Alfan. 1983. Crown rot of alfalfa in Utah. Phytopathology, $73: 1333-1337$.

21. Uddin , W. and T.R. Knous. 1991. Fusarium species associated with crown rot of alfalfa in Nevada. Plant Dis., $75: 51-56$.

22. Uzma, S. and H. Nusrat. 2011. Studies on the efficacy of chemical and nonchemical treatments to control mycoflora associated with Chilli seeds. Pak. J. Bot., 43(1): 95-110.

23. Zhang, B.Q. and X.B. Yang. 2000. Pathogenicity of Pythium populations from corn- soybean rotation fields. Plant Dis., 84(10: 94-99.

24. Zwatz, B. 1991. Lucerne reservoir of infection by Verticillium wilt in alternative crops . Plfanzenschatz ( Wien ). Plant Pathol., 71 ( 6 ) : 33-58 ). 


\section{الأمر اض الفطرية للبرسيم الحجازي في محافظة الإسماعيلية}

\section{عبدالله متولي الجارحى' ، ضياء عبد الفتاح الوكيل'}

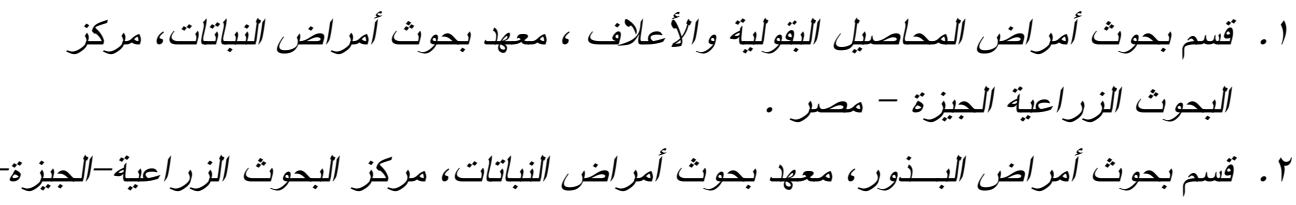

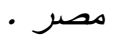

تم عمل حصر للأمر اض الفطرية على البرسيم الحجازى فى محافظة الإسماعيلية وقد تم هذا

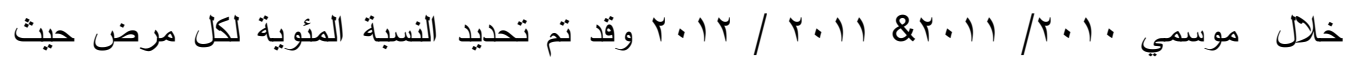

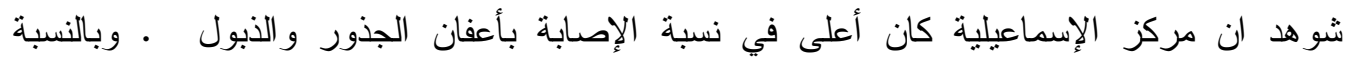
لأمر اض المجموع الجذري أتضح أن الفطريات التى تفتلك بالبرسيم الحجازى فى محافظة الإسماعيلية

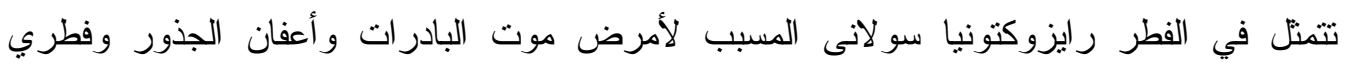

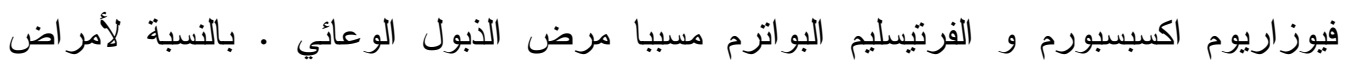

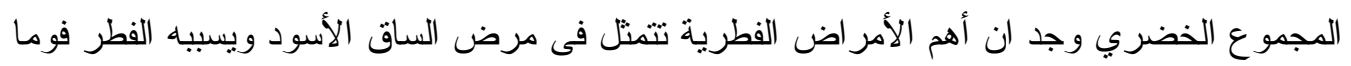

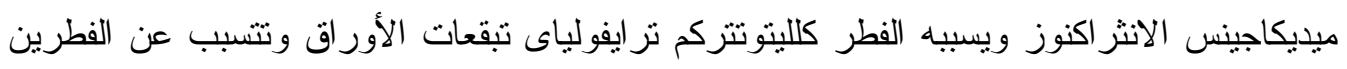

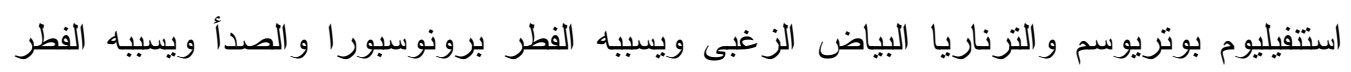

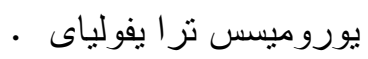

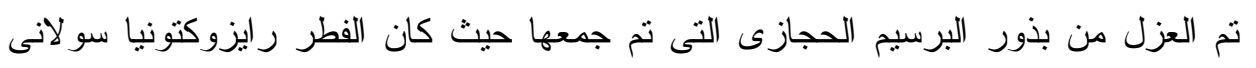

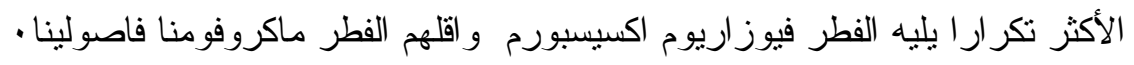
تم عمل اختبار القدره المرضيه على الاطباق فى المعل للفطريات المعزوله من بذور البرسيم الحجازي ووجد أن الفطر رايزوكتونيا سولانى الأعلى في القدرة المرضية يليه الفطر اسكروتينيا اسكروتيورم بينما كان الفطر ماكروفومنا فاصولينا الاقل فى هذا المجال. 